\title{
The Global Award for Entrepreneurship Research
}

\author{
Magnus Henrekson · Anders Lundström
}

Accepted: 27 May 2008/Published online: 15 October 2008

(C) Research Institute of Industrial Economics 2008. This article is published with open access at Springerlink.com

\begin{abstract}
The International Award for Entrepreneurship and Small Business Research was introduced in 1996, and it is now firmly established as the most prestigious award for outstanding research contributions in this subject area. Thanks to a generous donation from the Swedish entrepreneur Rune Andersson, it has been possible to make a number of changes aimed at strengthening global recognition of the Prize even further: the name is being changed to the Global Award for Entrepreneurship Research, the financial side to the Prize is being roughly doubled to 100,000 euros, and the system for nomination, evaluation, and selection of future Award Winners is becoming more structured and transparent. We present here the background to
\end{abstract}

Magnus Henrekson is CEO of the Research Institute of Industrial Economics (IFN) and Jacob Wallenberg Professor at the Stockholm School of Economics. Anders Lundström, who initiated the Prize, was the CEO of the Swedish Foundation for Small Business Research (FSF) from 1997 to 2008. He is also Visiting Professor at the School of Innovation, Design and Engineering, Mälardalen University.

M. Henrekson ( $\square$ )

Research Institute of Industrial Economics (IFN),

P.O. Box 55665, 10215 Stockholm, Sweden

e-mail: Magnus.Henrekson@ifn.se

URL: www.ifn.se/mh

\section{A. Lundström}

Swedish Foundation for Small Business Research, Järntorgsgatan 3, 70361 Örebro, Sweden

e-mail: lundstrom@fsf.se and the organization(s) behind the Award, briefly categorize the winners in the 1996-2008 period, describe the present and the future system for nomination, evaluation, and selection of Award Winners, and discuss the criteria for the selection of Prize candidates and Award-winning contributions.

Keywords Entrepreneurship - Innovation · Research award · Small business

JEL Classifications $\quad$ L5 $\cdot$ L26 $\cdot$ M13 $\cdot$ O31

\section{Introduction}

In 1996 the Swedish Foundation for Small Business Research (FSF) and the Swedish Agency for Economic and Regional Growth (NUTEK) established the International Award for Entrepreneurship and Small Business Research (also known as The FSFNUTEK Award). This Prize is awarded annually and consists of the statuette "The Hand of God", created by Swedish Sculptor Carl Milles, ${ }^{1}$ and a financial

\footnotetext{
${ }^{1}$ Carl Milles was arguably Sweden's most prominent sculptor in the 20th century. "The Hand of God" was one of Milles' last works before his death. Originally, Milles created it to honor the Swedish innovator and entrepreneur C. E. Johansson who revolutionized precision measuring of auto and other industrial parts which made the assembly line possible, and the original still stands in Johansson's hometown of Eskilstuna.
} 
award of SEK 0.5 million in 2008 (roughly USD $80,000)$.

In the 13 years since its inception the Prize has become firmly established as the foremost global award for research on entrepreneurship. ${ }^{2}$ In 2009 the Research Institute of Industrial Economics (IFN) is joining FSF and NUTEK to become the third partner in awarding the Prize. At the same time, the Prize sum is being increased to 100,000 euros (roughly USD 150,000 in 2008), and the procedure for nominating and evaluating prospective Award Winners is being strengthened. The name of the Prize is also being changed into the Global Award for Entrepreneurship Research. The partnership of IFN has become possible thanks to a generous donation by the Swedish entrepreneur and industrialist Rune Andersson and his holding company Mellby Gård AB.

Given that the Prize is now entering a new phase, we deem the time ripe to present the Award more broadly, and in this article we cover the following aspects: a brief presentation of the organizations behind the Prize, the nomination and selection process of Winners, and a presentation and categorization of Award Winners between 1996 and 2008. The categorization of the 1996-2008 Winners later in this essay provides the backdrop for a central part of this article, namely the discussion of the appropriate criteria for the selection of future Award Winners. We also describe herein the system that will be used, effective from 2009, to nominate, evaluate, select and

\footnotetext{
Footnote 1 continued

Throughout the 1930s Milles worked at Cranbrook Academy of Art near Detroit. Thanks to a contribution from the United Auto Workers, "Hand of God" was recast and donated to the city of Detroit in honor of Frank Murphy, Michigan Governor and U.S. Supreme Court Associate Justice. It now stands outside the Frank Murphy Hall of Justice in Detroit.
}

2 The Kauffman Foundation established the Kauffman Prize Medal in 2005. The Medal, which includes a USD 50,000 prize, is awarded every 2 years to one scholar under the age of 40 years who is working in the USA and "whose research has made a significant contribution to entrepreneurship." The inaugural Medal Winner was Scott Stern, an economist from Northwestern University's Kellogg School of Management, and in 2007, the Medal was awarded to Toby Stuart, an organizational sociologist at Harvard Business School. present Award Winners as well as discuss at some length the criteria for identifying a "prize-worthy" contribution.

\section{The background to and the organizations behind the prize}

The Swedish Foundation for Small Business Research started operations in 1994, with objective of serving as a bridge between the Swedish small business research community and parties involved in the development of new and small enterprises. To this end, it initiates and disseminates policy-relevant research on small businesses and entrepreneurship, and it offers entrepreneurship scholars and practitioners a forum for networking and sharing ideas. Research is conducted in program form, either within the FSF or in association with various universities and colleges throughout Sweden. The FSF has four broad research programs at the present time: growth and dynamics in the Swedish business sector, public sector entrepreneurship, entrepreneurship and innovation policy, and local and regional business development. A few years ago, FSF initiated cooperation with sister organizations in 14 European countries, the so-called IPREG project (Innovative Policy Research for Economic Growth, see www.ipreg.org). The Award Winners together with experts and research scholars from eight countries and the European commission are members of the FSF International Council, which meets twice annually. The FSF also has a Scientific Forum consisting of some 60 full and associate professors in Sweden. In total, FSF cooperates with close to 200 researchers in Sweden and internationally. The Swedish government contributes roughly $55 \%$ to the funding/working costs.

The Swedish Agency for Economic and Regional Growth is a government authority founded with the purpose of contributing to the creation of new firms, a larger share of expanding businesses, and less regional disparity in terms of economic growth and employment creation. To this end, it develops and disseminates relevant knowledge, tools, and methods, runs and supports programs fostering small and new firms in selected areas, counsels entrepreneurs, takes decisions on and co-ordinates regional support for enterprises, and gathers data and conducts analyses on which (future) government decisions can be based. 
In 1996, FSF and NUTEK hosted the International Council for Small Business (ICSB) World Conference in Stockholm. During the planning of this conference, Anders Lundström first presented the idea to establish an award for outstanding contributions in the field of entrepreneurship and small business research. The first Prize was to be awarded at the 1996 world conference. The obvious objective was to focus the limelight on a vibrant and rapidly expanding research field that deals with issues of crucial importance for future prosperity, while at the time being largely neglected in the discussion of economic development and policy-making. In order to establish an Award with great standing within the research community, it was decided both that the Prize sum should be sizeable and that the nomination, evaluation, and selection process associated with the Prize had to meet the highest standards.

One of the first steps was to contact Sveriges Riksbank (the Central Bank of Sweden) to enquire whether they were willing to participate. This seemed natural given that they had established the Sveriges Riksbank Prize in Economic Science in Memory of Alfred Nobel in 1968. A letter was sent to the Governor of the Bank. The proposal was formally rejected since, according to the Governor, the Bank was not allowed to inaugurate such an award. Luckily enough, the reply from the Governor was cited by a Swedish journalist in an article in a leading newspaper. In turn, this article was read by a high-ranking manager at the leading Swedish telecom company, Telia, and following one year of negotiations and discussions an agreement was signed that made Telia a partner of the Award together with NUTEK and FSF. The Prize sum was set to USD 50,000, and it was decided that the above-mentioned statuette "The Hand of God" would also be part of the Award.

The project period was initially set to 3 years. Thanks to the positive response both from the research community and the general public it was then extended, and the Award was made permanent with FSF and NUTEK as principals. At this point in time, the Prize was strengthened by combining the formal Award ceremony in Stockholm with other ancillary activities, such as the "Entrepreneurship Week", which consists of a number of seminars and events in cooperation with regional organizations around Sweden, with the Award Winner(s) and his/ her research holding center stage. Interest in the
Entrepreneurship Week has been growing over the years; an increasing number of organizations participate, and new locations and universities express an interest in organizing events during the week.

The Award Winners automatically become members of the FSF International Council, and most of the Winners of the first 10 years of the Prize wrote position papers for the 10th anniversary of the Award. These papers were published in a special issue of Foundations and Trends in Entrepreneurship (Lundström and Halvarsson 2006). Furthermore, the Award Winners have figured prominently on plenary panels at international academic conferences, and the EU Commission has shown great interest in their research. To handle the many ancillary activities added over the years, FSF and NUTEK employed a full-time project manager in 2002.

To measure the public awareness of the Prize in specifically targeted groups, an independent consultancy firm conducted surveys in 2005 and 2007. It turned out that close to $75 \%$ of all respondents were familiar with the Prize and the Winners. Hence, the Award is now firmly established, and the stage is set for the next step ahead, which includes adding a new partner, namely the Research Institute of Industrial Economics.

The IFN is a private non-profit research institution founded in 1939 that focuses on carrying out independent, non-partisan, high-quality academic research in economics. In addition, IFN provides high-quality analysis and policy recommendations for public and private decision-makers on current and emerging policy issues of relevance for the business sector.

The Confederation of Swedish Enterprise is the principal backer of the IFN, contributing some 35\% of the operating budget. The remainder is financed by research grants obtained in competition with other leading departments and institutions in the field. Research is conducted within four broad program areas: globalization and corporate restructuring, competition and trade in services, the economics of entrepreneurship, and the economics of electricity markets. With few exceptions, the research staff of roughly 20 full-time scholars hold a doctorate in economics.

These three organizations, the FSF, IFN, and NUTEK, are jointly responsible for the Global Award for Entrepreneurship Research. The process 
associated with the nomination, evaluation, and selection of Award Winners from 2009 and onwards is discussed later in this article. In short, a project group decides upon the administration and furthering of the Award and of the various ancillary activities, while FSF and NUTEK continue to take responsibility for the marketing and dissemination activities, such as the production of information material and the planning and enactment of the Entrepreneurship Week. ${ }^{3}$ The IFN is responsible for commissioning and preparing the scientific evaluations of the main candidates for the Global Award, to assist in the formulation of the formal motivation for the Awardwinning contributions, and to ascertain that an essay on the contributions of the Award Winner(s) as well as a publishable Prize Lecture are produced for publication in Small Business Economics. The work is coordinated by the project group and the project manager. The project group also has the joint task of developing and maintaining the new website for the Global Award.

\section{The nomination and selection process 1996-2008}

According to the original statutes, the Award should be given to "a person who has produced scientific work of outstanding quality and importance, thereby giving a significant contribution to theory-building concerning entrepreneurship and small business development, the role and importance of new firm formation and the role of small- and medium sized enterprises (SMEs) in economic development." Hence, the prime reason for receiving the Award is outstanding scientific achievement. Other factors, however, may also be factored in. This was made explicit by Anders Lundström and Sune Halvarsson (2006), the then CEOs of FSF and NUTEK, respectively, who stated that the ambition behind the Award is threefold: (1) to highlight the importance of research produced in the areas of entrepreneurship and small business; (2) to further stimulate and

\footnotetext{
3 This also includes the marketing of two other awards, namely, the annual award to a young Swedish entrepreneurship scholar (not older than 35) and that for the international projects of student entrepreneurs. IFN has no part in these activities.
}

promote research within these fields; (3) to diffuse the state-of-the art research among scholars, practitioners, and people involved in small business development.

Since the inception of the Prize, an invitation has been extended in June of each year to almost 400 leading entrepreneurship and small business scholars world-wide to nominate candidates. The selection of the Award Winner is then made by a Prize Committee, which also has the right to nominate candidates. The Committee consists of six to eight members, and in order to be eligible, the candidate has to be a full professor at a Swedish university working on small business and entrepreneurship issues. Committee members are appointed by the board of FSF for a standard term of 2 years; the chairperson is elected for 1 year. One can be reelected both as a member and as a chairman for additional terms. Table A1 in the Appendix lists the names of the Committee members and their terms of office during the period 1996-2008. It should be noted that the Committee's work takes place in the year preceding the announcement of a certain Winner. Hence, being chairman in 2004 implies chairing the Committee selecting the 2005 Winner, and so on.

The discussions within the Committee are strictly confidential and remain within the Committee. The various considerations that are used to assess individual Prizes and candidacies are never communicated to individuals and/or organizations outside of the Committee. However, it is still possible, based on the list of Winners in the first 13 years of the Award, to reflect in general terms on the criteria used, categorizations of scholars, and types of research awarded.

\section{Presentation and categorization of previous winners}

It is clear from the statutes that it is possible to reward both research focusing on the aggregate effect of small firms and entrepreneurial activity and research dealing with micro aspects of small businesses and entrepreneurship where the object of study is the individual entrepreneur or firm.

This is not the place to elaborate in detail on the contributions of Award Winners. Landström (2005) provides a thorough account of the contributions and 
careers of all Winners through to 2002. Since 2003, the contributions of the Winners are presented in an essay in Small Business Economics written by one or several members of the Prize Committee, in some cases with an outside co-author possessing particular expertise of the scholar in question. ${ }^{4}$

Table 1 provides a brief presentation of all Award Winners until 2008. On two occasions the Prize was shared between two scholars (Acs/Audretsch and Beccatini/Sabel) and once the Prize was awarded to a specific research effort (Diana) involving five scholars (Brush/Carter/Gatewood/Greene/Hart). Hence, to date there have been 19 Award Winners. The Prize is normally awarded to one person only, but in the case of the Prize shared by Acs/Audretsch, it is obvious that the Committee felt that the contribution that was being awarded was inseparably tied to the joint efforts of the two scholars. When the Prize was shared by Beccatini/ Sabel, it was rather the case that the analysis of a particular phenomenon, namely the advantages of a geographical agglomeration of specialized small firms ("Industrial Districts"), was rewarded. The Committee decided to give the Prize to what they considered to be the two most influential contributors on this issue. A similar reasoning lay behind the Award to the five scholars behind the Diana group.

With respect to the main affiliation of the Winner at the time of receipt of the Prize, there has been a heavy domination of U.S. researchers. Of the 19 winners to date, 15 were affiliated exclusively to U.S. institutions. In two cases (Storey and Johannisson), single Winners came from other countries (the UK and Sweden). One of the Winners (Reynolds) held professorships both in the USA and the UK when he received the Award, and Beccatini, from Italy, shared the Prize in 2002.

While emphasizing the difficulties of drawing a sharp demarcation line between micro- and macrooriented research on entrepreneurship and small businesses, we attempt here to categorize the research of the Winners to date within this framework. ${ }^{5}$ As

\footnotetext{
${ }^{4}$ See Eliasson and Henrekson (2004), Davidsson (2005), Hjorth and Johannisson (2008), Douhan et al. (2007), Holmquist and Carter (2008), and Landström and Steyaert (2009) for presentations on the contributions of Winners in the 2003-2008 period.

5 This was also done by Landström (2005) for all Winners through to 2002. Our classification concurs with that of Landström's in this respect.
}

shown in Table 1, in our assessment, five Prizes have been awarded to research dealing with the macro importance of new and small firms, two Prizes (Baumol and Kirzner) to research focusing on the role and aggregate importance of entrepreneurship (i.e., the entrepreneurial function) in the economic system, and six Prizes to scholars conducting micro level analyses of entrepreneurship and small businesses.

It is also evident that although all Winners have had a profound impact on entrepreneurship and small business research, how this has come about differs considerably. In some cases, scholars have posed the right questions at the right time while concurrently framing their analysis in such a way that has speeded the diffusion of their ideas. As a result, these scholars have kept the research community busy for decades collecting data, testing hypotheses, amassing evidence, and, in some cases, leveling heavy criticism against the original work. This is true for both Birch and Sabel who (the latter in particular together with Michael Piore in their famous 1984 book) built on and disseminated Beccatini's research outside Italy. ${ }^{6}$ Birch has not published a single peer-reviewed journal article in the field, and Becattini and Sabel have produced broad and accessible analyses drawing on historical and contemporary evidence. Their analyses are highly persuasive and easily communicated to policy-makers and the general public. $^{7}$

Although entrepreneurship and small business research is a young field and, therefore, has but a short history, it is still true that there has always been a pool of excellent people for the Prize Committee to choose from. In particular, there are several pioneers

\footnotetext{
${ }^{6}$ A famous parallel case is Paul Krugman's (1991) popularization of economic geography, a field that had been highly specialized was then brought to the attention of mainstream economists, and thereby also to the forefront of the policy discussion.

7 The enormous impact of these technically unsophisticated contributions bear witness to Lawrence Summers' (1991) criticism of modern macroeconomics, where he claims that most of the empirical work that actually furthers our knowledge tells its story regardless of the precise way in which it is analyzed: "In large part, it is its simplicity that makes it persuasive."
} 


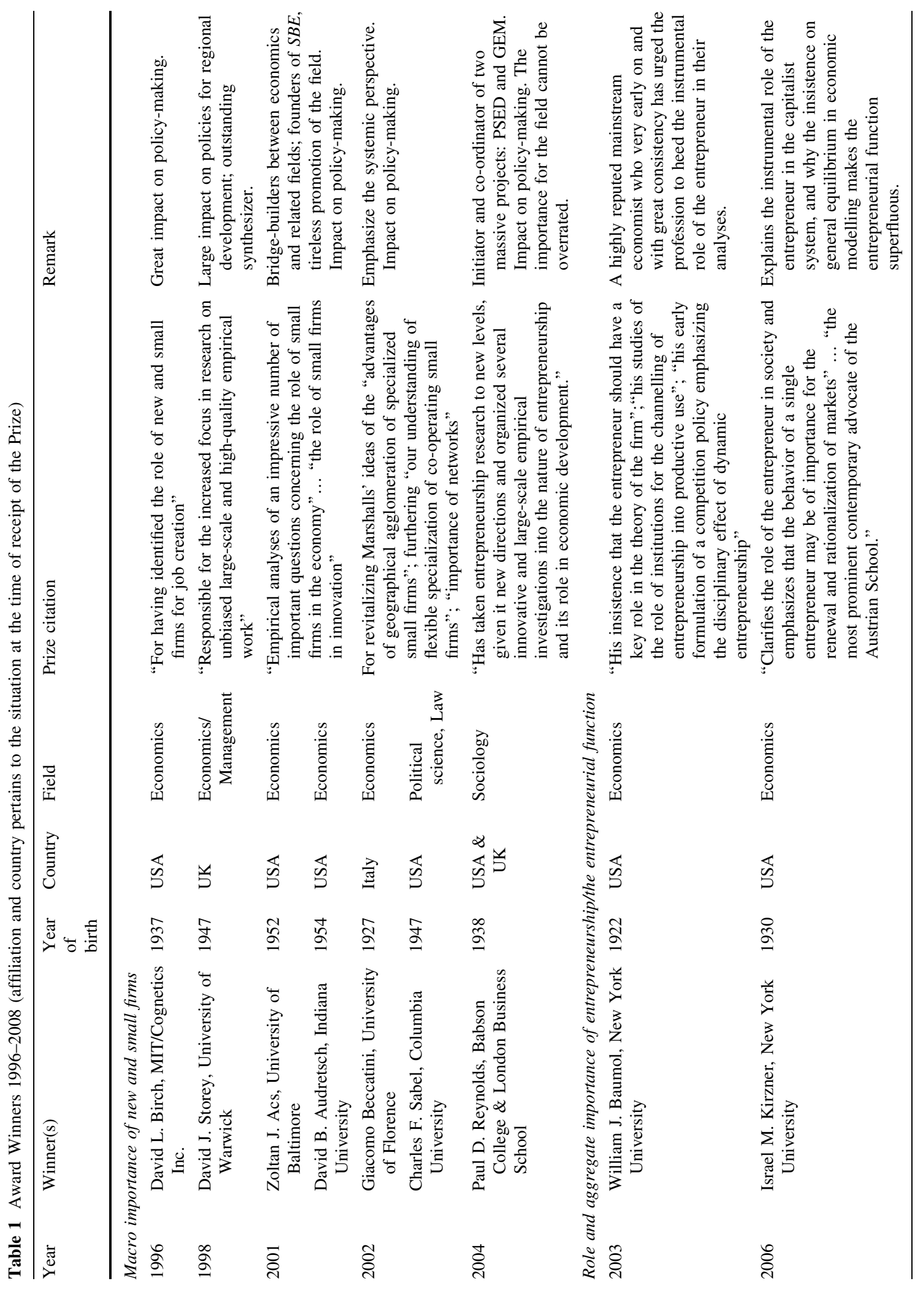




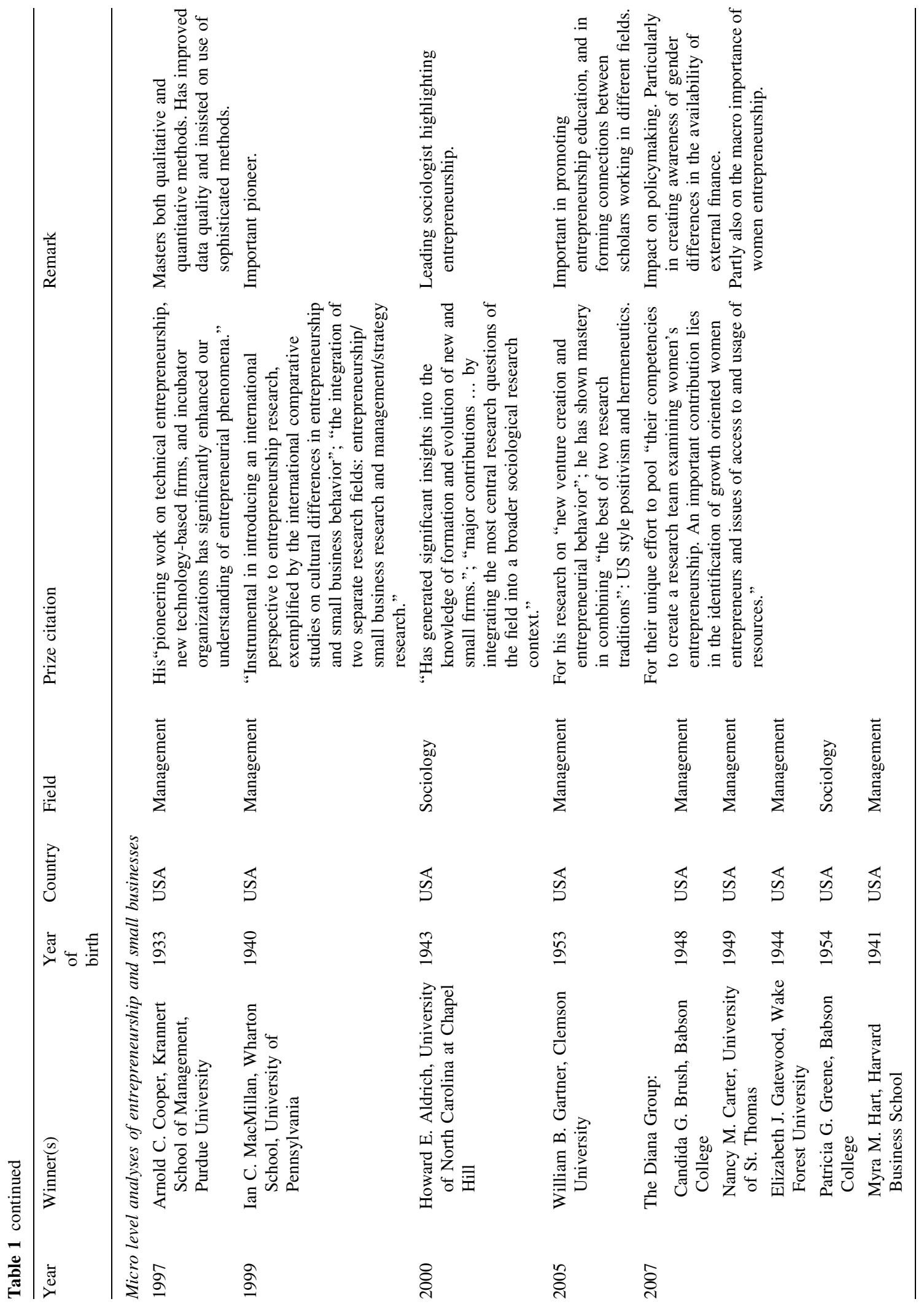




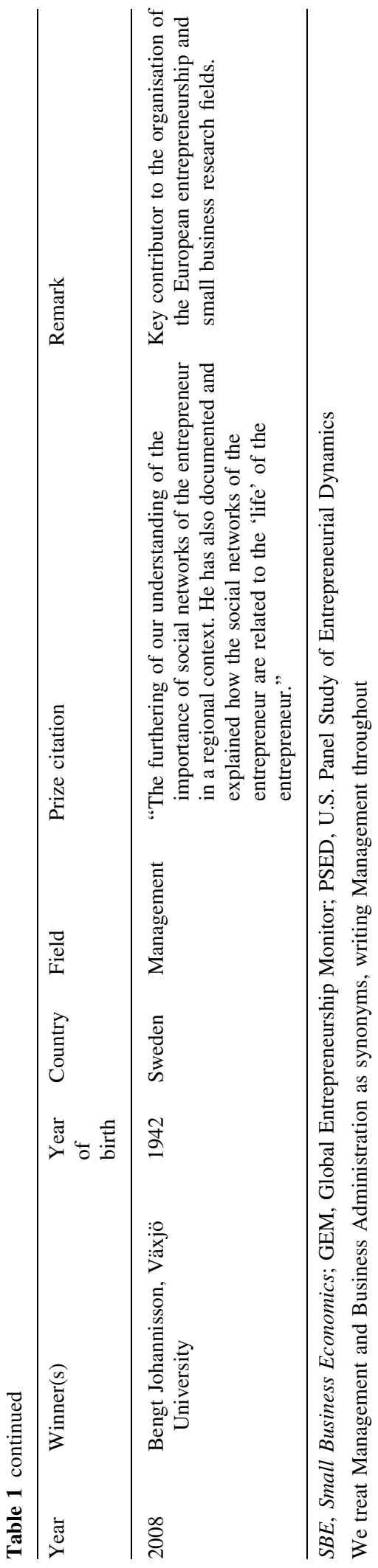

that are highly visible and readily recognized by virtually every scholar working in the field. Even a cursory look at the list of Winners in Table 1 makes it clear that virtually every Winner to date can be labeled a pioneer in some important respect. In most cases, those pioneers have not only contributed in terms of their own research, but they have also been active in promoting entrepreneurship education and the field itself in a wider sense by starting journals, organizing conferences, and writing influential surveys, all of which have set the agenda for further research.

The most obvious research pioneers are Arnold Cooper and Ian MacMillan, who started pushing and giving legitimacy and academic credibility to entrepreneurship research long before the appearance of David Birch's highly publicized work. Bengt Johannisson played a similar pioneering role in Scandinavia. Birch's work highlighted the key role of small firms and Gazelles in job creation, thereby changing the perception of the policy relevance of the field more broadly.

Several scholars have been awarded the Prize-at least in part-for their instrumental role in helping entrepreneurship research progress towards more of a "normal science" using systematically collected and valid data for hypothesis testing and, thereby, making the work in the field more cumulative. David Storey and Paul Reynolds are perhaps the two most obvious examples of Winners who have contributed to the field in this way.

There are also examples of Award Winners who were highly renowned scholars in a core scientific discipline and then ventured into the study of entrepreneurship using the same well-established methodological toolbox. Hence, they made the study of entrepreneurship an important subfield within a core discipline and thereby raised the legitimacy of entrepreneurship as a field of research. A prime example is Howard Aldrich, who was a leading organization sociologist before he stumbled onto entrepreneurship issues in the 1980s.

In several cases, individuals have been awarded the Prize for the study of specific issues or topics. The Diana group and Beccatini/Sabel are perhaps the most obvious cases in point. Other examples include Bill Gartner for his extensive studies of new venture creation and entrepreneurial behavior, although he was also rewarded for bridging different research 
paradigms and the communities of scholars that represent them. Acs/Audretsch can also be said to have been largely rewarded for the study of a specific issue, namely, the crucial importance of new and small firms in innovation. However, their contribution goes well beyond that in that they more or less single-handedly created the field of small business economics, including the establishment of Small Business Economics.

Finally, we have the Prizes to the two economists William Baumol and Israel Kirzner. It is well-known that there is no role for the entrepreneur in the basic microeconomic model of the firm or in the standard aggregate (exogenous or endogenous) models of economic growth. ${ }^{8}$ Baumol, who is a highly reputed mainstream economist, forcibly pointed this out back in 1968 and has insisted ever since in numerous scholarly books and articles that without the entrepreneur, economics is blatantly incomplete. Kirzner, on the other hand, has been a heterodox economist throughout his career working in the Austrian tradition. Building on von Mises' and Hayek's analyses of competition and the role of knowledge, he has analyzed the workings of the capitalist system where the entrepreneur is the lead character.

In summary, this brief overview of previous Award Winners shows that there is great diversity in their work and achievements. These vary from both quantitative and qualitative works, micro- and macro-oriented focus, a wide range of publication outlets from easily accessible books and reports to highly specialized scholarly articles, from the development of new data sets to conceptual and methodological improvements, from having great impact on the research community to having an impact on policy-making, and the promotion of education and training in entrepreneurship.

\section{System for nomination, evaluation, selection, and presentation of future award winners}

The nomination, evaluation, and selection of Award Winners is delegated to an autonomous Prize

\footnotetext{
${ }^{8}$ See, for example, Barreto (1989) and Bianchi and Henrekson (2005), respectively.
}

Committee, which is elected by the board of FSF. From 2009 onwards, the members and chairman of the Prize Committee will be elected for a term of 3 years, and the Committee will consist of six members, giving the chairman the decisive vote in the case of a split Committee. In order to ascertain continuity, no more than two members should be replaced in a given year. The Committee members are appointed solely based on their scientific credentials. They are expected to be leading academics in the field and to have reached the level of full professor or the equivalent. A chairman cannot be reelected for a consecutive term, but Committee membership can be extended for an additional 3-year period. In exceptional cases, it is possible to be reelected for a third consecutive term. After an interim of at least 3 years a previous Committee member can once more be elected.

As already noted, the Prize is entering a new phase beginning with the 2009 Award Winner. Most obviously, the increased resources made available through a generous donation from the Swedish entrepreneur Rune Andersson and his holding company Mellby Gård $\mathrm{AB}$ will make it possible to raise the Prize sum to 100,000 euros, an approximate doubling of the previous sum of SEK 500,000 awarded in recent years.

An equally important improvement is to continue to increase the stringency and thoroughness of the process for the evaluation and selection of future Winners. As already mentioned, a number of distinguished entrepreneurship scholars will be invited to nominate candidates. This invitation has been extended every year since 1995. From 2009 onwards, this will be done in a structured and transparent manner, where an invitation to nominate will be extended to:

- All previous Award Winners;

- The editors and the members of the editorial boards of the journals in entrepreneurship and small business research included in the Social Sciences Citation Index. At present, the following six journals qualify: Journal of Business Venturing, Entrepreneurship Theory and Practice, Small Business Economics, Entrepreneurship and Regional Development, Journal of Small Business Management, and International Small Business Journal; 
- Present and past members of the FSF Scientific Forum who also hold or have held positions as full professors.

Self-nominations are disallowed, but members of the Prize Committee will continue to have the right to nominate candidates. These nominations provide the first step in the creation of a list of potential candidates to be considered by the Prize Committee. It is at the discretion of the Committee to decide which candidates should be targeted for a more thorough evaluation. A candidate can be on the list for several years and, therefore, during that entire time be regarded as a potential candidate for the Award.

The Prize will be awarded for the 14th time in 2009. In the first few years there was an obvious backlog of worthy candidates, primarily scholars widely recognized as key contributors to the budding field of entrepreneurship and small business research. However, as time elapses, fewer and fewer candidates are receiving the same wide agreement from the scientific community as the first candidates. The backlog is gradually being depleted while, at the same time, the field of entrepreneurship research has expanded and is still expanding at a rapid rate. Therefore, it is imperative to improve the highquality selection process characterized by continuity and robustness. The eventual selection of the Winner needs to be based on thorough evaluations and comparisons of a number of worthy candidates, and the pool of candidates from which the Winner is selected must be reasonably stable, reflecting the long-term efforts of the Prize Committee. To this end, it has been decided that the Prize Committee "inherits" a limited number of short-listed candidates from the previous year, and-except in rare casesthe Winner will be selected from this pool of shortlisted candidates. However, the Committee is also commissioned to add one or two new candidates to this pool based on nominations and discussions in that year (and previous years).

All short-listed candidates will be thoroughly evaluated by a specialist in the candidate's field. ${ }^{9}$

\footnotetext{
$\overline{9}$ The use of solicited expert reports to evaluate strong candidates is in line with the procedure of the Nobel Prize Committee; see Lindbeck (2007).
}

These outside evaluations are strictly confidential. The evaluation of a Winner by the commissioned expert will form the basis for a published presentation of the Winner co-authored by the outside expert and the member of the Prize Committee who is most familiar with the Winner's work. In some cases, the commissioned expert may be a member of the Prize Committee, but this is likely to be an exception rather than a rule.

The name of the Award Winner will continue to be announced at FSF's Annual Conference ("Small Business Days") in the city of Örebro, central Sweden, in late January. After the announcement, the Award Winner will be requested to prepare a publishable Prize Speech that can be delivered at the official Award ceremony in Stockholm in September. Also, the Award will still be given by the Minister of Enterprise, Trade and Communication, and the Winner is then expected to tour Sweden during the Entrepreneurship Week, the annual seminar tour of Swedish university cities taking place during the week (in September) when the Award is conferred. The ambition of the Committee is that both the essay presenting the contribution of the Winner and the Prize speech are published in Small Business Economics shortly after the Prize is awarded.

A new website for the Award has been developed from scratch. This contains an overview of the Prize, criteria for selection and nomination, systematic presentations of all Award Winners since 1996, the Prize speeches of said Winners and other pertinent information about the Winners and the entrepreneurship field more generally. The website is located at www.e-award.org and is also easily found via the websites of the three organizations hosting the Prize (www.fsf.se/e-award, www.ifn.se/e-award, and www. nutek.se/e-award).

Resources have been ascertained to have an active research scholar in the entrepreneurship area spending up to $25 \%$ of his/her time on researching the Prize, building, and updating the website etc. The scholar will initially be tenured at IFN.

From 2009 onwards, the term "small business" is to be dropped from the name of the Prize. An obvious advantage of this change is a shortening of its name, but it also reflects the fact that the Committee wishes to emphasize that this is an Award for research on entrepreneurship, irrespective of whether this entrepreneurship takes place in small firms or in other 
types of organizations. In practice, research on small firms will continue to play a great role among the Award-winning contributions, since entrepreneurship is so often tied to new and small businesses.

\section{Criteria for the selection of future winners}

So what is a worthy contribution? This is a key question lacking a precise answer, but it must nevertheless be elaborated upon. Naturally, there have been lengthy discussions on this subject among the members of the Prize Committee over the years, and what appears in the following paragraphs is greatly inspired by those discussions and by inputs from current and previous Committee Members on an earlier version of this text. Assar Lindbeck's (1985, 2007) insightful discussion of the criteria used to select the Nobel Prize Winners in Economic Science has also been an important source of inspiration.

First and foremost, a prize worthy contribution needs to be original and influential. One can think of many ways in which a contribution is influential, notably through its impact on subsequent scientific work (normally by virtue of the scientific work per se, but sometimes through the organization of large research programs), by furthering entrepreneurship as a field (by creating important data bases, by starting influential journals, scientific communities, etc.), by furthering entrepreneurship education and training at the academic level, and by influencing policy-making and society more broadly. However, it takes time before one can be reasonably sure that a contribution is both original and influential - rather than a virulent fad that will taper off with only negligible long-run effects. One needs to allow the requisite time for potential criticism and scrutiny by other scholars before one can be sure that the contribution is as solid as it first appeared to be. Therefore, a certain caution and "conservatism" can be expected, also in the future.

A prime ambition of the Prize Committee is that over a longer time span the Award-winning contributions should reflect the extraordinary width of entrepreneurship as a social science field, spanning the entire spectrum from anthropology to theoretical microeconomics as well as methodological diversity from hermeneutics to formalized deductivism via traditional hypothesis testing by means of state-of-the art statistical methods. Therefore, the Committee cannot be rigid about what type of work is rewarded, such as setting up a rule that articles in peer-reviewed journals is the sole type of publication that counts.

Yet another dimension revolves around which aspects of entrepreneurship can be rewarded. Here at least three important aspects come to mind: (1) the environment and the organizations in which entrepreneurship is conducted; (2) the character of the entrepreneur (personality, cognitive, and affective aspects); (3) the role of the entrepreneur and/or the entrepreneurial function in a wider sense (at the level of the community, region, country, industry). ${ }^{10}$ All three aspects are highly relevant, and a scholar may be rewarded for contributions to any of them. Highquality research that manages to connect two or all three aspects in a coherent framework is rare and, therefore, looked upon favorably.

Given that the Prize should reflect the width and diversity of the field, one should expect a shifting over the years of candidates across fields and research traditions. When there is a close race, it is also natural to give priority to contributions which have more clearly withstood "the test of time."

In most cases the Committee will single out one individual who has made one or several outstanding contributions to the field in one or several of the dimensions mentioned above. It seems likely that, as the field matures and becomes more specialized and methodologically sophisticated, the share of scholars who are rewarded for producing original and influential scientific work per se will increase. This reflects the fact that crucial pioneering efforts in building databases, starting journals, among numerous other initiatives will gradually wane in importance as a field becomes more firmly established.

In other cases, the Prize Committee may decide that a specific phenomenon (e.g., female entrepreneurship, the role of small firms in innovation, or the "Industrial District") or a novel subdiscipline should be awarded. Under this circumstance, there will likely be more than one Award Winner.

\footnotetext{
${ }^{10}$ These three aspects can be seen as one way of operationalizing Venkataraman's (1997, p. 120) definition of entrepreneurship as a scholarly field: "seeks to understand how opportunities to bring into existence 'future' goods and services are discovered, created, and exploited, by whom, and with what consequences."
} 
When selecting Prize-worthy contributions (both actual Winners and nominees added to the shortlist of individuals evaluated by an outside specialist), the Committee has and will largely rely on qualitative judgment. Quantitative methods, such as citation counts and impact factor-adjusted publication volumes will continue to provide important complementary information about candidates, but they will never substitute for qualitative judgment. Nor will the Prize be given as a sort of life-time achievement award to scholars who have managed to amass an extraordinary volume of solid, well-published works, but where none of it stands out as original and truly influential. Hence, quantity cannot substitute for quality, and it is possible to give the Award to a scholar even for a single landmark contribution. ${ }^{11}$

\section{Concluding remarks}

Since its inception in 1996 the International Award for Entrepreneurship and Small Business Research has become firmly established and widely recognized as the leading international Award in its subject area.

Effective from 2009 a number of changes are being put into effect with the aim of strengthening and raising the prestige of the Prize even further: (1) the name has been changed to the Global Award for Entrepreneurship Research; (2) the Prize sum has been increased to 100,000 euros; (3) the system for nominating, evaluating and selecting future Award Winners is becoming more structured and transparent. In this essay we have presented the background to and the organizations behind the Award, categorized Winners in the 1996-2008 period, described the previous and future system for the nomination, evaluation, and selection of Award Winners and discussed the criteria for the selection of Prize candidates and Award-winning contributions.

As a final note it may be worth asking whether the benefits of a Prize of this kind exceed the direct and

\footnotetext{
11 This is not without precedence. Among the Nobel Laureates in Economic Science this is fairly common. John Nash, Michael Spence, Myron Scholes, Bertil Ohlin, Harry Markowitz, George Akerlof, Finn Kydland, and Robert Solow are prime examples. A few of them have fairly long publication lists, but it was one or two fundamental contributions that earned them the Nobel Prize. See Lindbeck (2007).
}

indirect costs involved. Obviously, there is little need to spend resources on convincing the community of research scholars in the area that entrepreneurship and individual entrepreneurs are of crucial importance for economic progress and job creation. However, this is by no means the conventional wisdom in mainstream economics and management. To the extent that a prestigious Award can help disseminate the state-of-the art research among scholars, practitioners, and people involved in small business development, considerable good may be achieved by the existence of such an Award.

An Award of this kind may also function as a source of inspiration for other scholars. First, at least for some scholars, it is likely to provide an incentive in itself, a remuneration-both financial and personal-to aim for. However, more importantly, it allows researchers to focus on pursuits that are seldom highlighted in the public eye but which are still of major importance. The recipient of this Award can be an example of a hero that is radically different from the lavishly paid movie actors, athletes, and finance wizards, and recognition of these recipients publicizes the fact that their insights and findings can make a big difference for our communities and our well-being.

The fact that quality is systematically favored over quantity when the Winner is selected may hopefully provide scholars with stronger incentives to produce high-quality research rather than large amounts of passable research. It is also important to bridge the communication gap that arises when increasingly specialized researchers study similar phenomena using diverse methods and concepts unique to their own discipline. Interdisciplinarity may be heralded in theory, but it tends to be shunned in practice. This Award and the growing stock of Award Winners points to the diversity of entrepreneurship research, and it may also show that those who succeed in crossing disciplinary boundaries in interesting ways are sometimes profusely rewarded.

Acknowledgments We are grateful for useful comments and suggestions from a number of colleagues, notably Pontus Braunerhjelm, the new CEO of FSF, and Leif Lundblad Professor at the Royal Institute of Technology, Stockholm.

Open Access This article is distributed under the terms of the Creative Commons Attribution Noncommercial License which permits any noncommercial use, distribution, and reproduction in any medium, provided the original author(s) and source are credited. 


\section{Appendix}

Table A1 Members of the Prize Committee, 1995-2008

\begin{tabular}{|c|c|c|}
\hline Name & Affiliation & Position/Period \\
\hline Pontus Braunerhjelm & Royal Institute of Technology, KTH & Member 2006-2008 \\
\hline Per Davidsson & Jönköping International Business School & Member 1998-2003 \\
\hline Gunnar Eliasson & Royal Institute of Technology, KTH & $\begin{array}{l}\text { Chairman } 2003 \\
\text { Member 2003-2008 }\end{array}$ \\
\hline Bertil Gandemo & Lund University & Member 1995-1999 \\
\hline Magnus Henrekson & Stockholm School of Economics and IFN & $\begin{array}{l}\text { Chairman 2007-2008 } \\
\text { Member 2002-2008 }\end{array}$ \\
\hline Carin Holmquist & Stockholm School of Economics & $\begin{array}{l}\text { Chairman 1995-1998, } 2004 \\
\text { Member 1995-2008 }\end{array}$ \\
\hline Claes Hultman & Örebro University & Member 1995-1999 \\
\hline Bengt Johannisson & Växjö University & Member 2003-2005 \\
\hline Sven-Erik Johansson & University of Skövde/Jönköping International Business School & Member 1995-1999 \\
\hline Hans Landström & Lund University & $\begin{array}{l}\text { Chairman 1999-2002 } \\
\text { Member 1995-2008 }\end{array}$ \\
\hline Åsa Lindholm-Dahlstrand & Halmstad University & Member 2006-2008 \\
\hline Leif Lindmark & Jönköping International Business School & Member 1995-1999 \\
\hline Christer Olofsson & Swedish University of Agricultural Sciences, SLU & Member 1995-1999 \\
\hline Sören Sjölander & Chalmers Institute of Technology & Member 2003-2005 \\
\hline Elisabeth Sundin & Linköping University & Member 1995-1999 \\
\hline Johan Wiklund & Jönköping International Business School & $\begin{array}{l}\text { Chairman 2005-2006 } \\
\text { Member 2004-2008 }\end{array}$ \\
\hline Ivo Zander & Uppsala University & Member 2007-2008 \\
\hline
\end{tabular}

The affiliation refers to the Committee member's affiliation at the time of service. The Committee's work takes place in the year preceding the announcement of a certain Winner. The Committee also awards a Prize to a Swedish entrepreneurship scholar aged 35 or younger. Originally, one male and one female scholar were given an award annually, but since 2008 there is only one Award Winner per year, alternating between male and female scholars

\section{References}

Barreto, H. (1989). The entrepreneur in economic theory. London and New York: Routledge.

Bianchi, M., \& Henrekson, M. (2005). Is neoclassical economics still entrepreneurless? Kyklos, 58(4), 353-377.

Davidsson, P. (2005). Paul D. Reynolds: Entrepreneurship research innovator, coordinator, and disseminator. Small Business Economics, 24(4), 351-358.

Douhan, R., Eliasson, G., \& Henrekson, M. (2007). Israel M. Kirzner: An outstanding Austrian contributor to the economics of entrepreneurship. Small Business Economics, 29(1-2), 213-223.

Eliasson, G., \& Henrekson, M. (2004). William J. Baumol: An entrepreneurial economist on the economics of entrepreneurship. Small Business Economics, 23(1), 1-7.

Hjorth, D., \& Johannisson, B. (2008). Building new roads for entrepreneurship research to travel by: on the work of William B. Gartner. Small Business Economics (in press).
Holmquist, C., \& Carter, S. (2008). The Diana Project: Pioneering Women Studying Pioneering Women. Small Business Economics (in press).

Krugman, P. (1991). Geography and trade. Cambridge, MA: MIT Press.

Landström, H. (2005). Pioneers in entrepreneurship and small business research. New York: Springer.

Landström, H., \& Steyaert, C. (2009). Bengt Johannisson's contribution to entrepreneurship and small business research. Small Business Economics (in press).

Lindbeck, A. (1985). The prize in economic science in memory of Alfred Nobel. Journal of Economic Literature, 23(1), 37-56.

Lindbeck, A. (2007). The Sveriges Riksbank Prize in Economic Science in Memory of Alfred Nobel 1969-2007. Available at: http://nobelprize.org/nobel_prizes/economics/articles/ lindbeck/index.html.

Lundström, A., Halvarsson, S., et al. (2006). Entrepreneurship research: past perspectives and future prospects. Foundations and Trends in Entrepreneurship, 2(3), 145-259. 
Piore, M. J., \& Sabel, C. F. (1984). The second industrial divide. New York: Basic Books.

Summers, L. H. (1991). The scientific illusion in empirical macroeconomics. Scandinavian Journal of Economics, 93(2), 129-148.
Venkataraman, S. (1997). The distinctive domain of entrepreneurship research. In J. Katz (Ed.), Advances in Entrepreneurship, Firm Emergence and Growth, Vol III (pp. 119-138). Greenwich, CT: JAI Press. 